\title{
ANALISIS SELL IN MAY AND GO AWAY DI BURSA EFEK INDONESIA DAN MALAYSIA PERIODE 2017-2019
}

\author{
Laila Marta Zarika \\ Universitas Negeri Surabaya \\ lailamarta28@gmail.com \\ R.A. Sista Paramita \\ Universitas Negeri Surabaya \\ sistaparamita@unesa.ac.id
}

\begin{abstract}
In May and Go Away (SMGA), Sell is a type of seasonal Anomaly, which historically originated in Europe and America that between May-October returns lower than the other periods from November to April. This research aims to determine the difference in abnormal return in the May-October (Worst period) period and NovemberApril (Best period) in Indonesia and Malaysia Stock Exchange between 2017 to 2019. This test conducted using the company's stock price data samples listed on the LQ45 index in the Indonesia Stock Exchange and the FBMKLCI index in the Malaysia Stock Exchange period 2017 to 2019. Hypothesis testing using paired sample t-test to answer if there is a difference in return between the best period and the worst period, to prove the Sell's existence in May and Go Away. The results showed no difference returns between the best and worst periods in the Sell in May and Go Away phenomenon at the Indonesia and Malaysia Stock Exchange period 2017 to 2019. The Investor considers SMGA as not a phenomenon containing excellent or bad information that is capable of affecting the price movement of shares so that SMGA as a strategy to buy stocks in the best period and sell in the worst period is no longer relevant.
\end{abstract}

Keywords: abnormal return; seasonal anomaly; sell in may and go away.

\section{PENDAHULUAN}

Investasi pada sektor pasar modal menjadi amat populer. Di Indonesia, hal ini dibuktikan dengan kenaikan jumlah SID (Single Investor Identification) pada data yang dirilis Kustodian Sentral Efek Indonesia (KSEI) tahun 2018. Rilis tersebut menyebutkan bahwa pada akhir Desember 2018, kenaikan jumlah SID mencapai 1.817 .367 , naik 44,06\% dari tahun sebelumnya. Di antara semua produk pasar modal, saham menjadi salah satu produk yang paling terkenal dan diminati oleh investor. Investasi saham kemudian menjadi sangat populer bersamaan dengan berkembangnya teknologi dan internet, di mana investor dapat dengan mudah bertransaksi dengan media komputer dan telepon genggam. Selain karena kemudahannya, Wicaksana (2018) berpendapat bahwa investasi saham menawarkan tingkat keuntungan yang tinggi, di mana kenaikan harga saham bisa menjadi sangat signifikan.

May (2017:13) menjelaskan dalam bahwa dalam melakukan investasi, setiap investor memiliki tujuan yang berbeda. Tujuan investasi yang paling umum adalah menjaga nilai mata uang dari inflasi, mendapatkan tambahan penghasilan hingga melipatgandakan aset. Setiap investor menginginkan imbal hasil (return) berupa material seperti capital gain, maupun non-material seperti rasa aman atas risiko penurunan nilai uang dari kegiatan investasinya.

Harga saham bergerak fluktuatif setiap waktunya sesuai dengan permintaan dan penawaran investor. Pada tingkat tertentu, permintaan dan penawaran akan menggerakan harga saham untuk naik maupun turun. Dalam melakukan keputusan beli maupun jual, investor sering kali berpegangan pada informasi yang beredar dan rekomendasi analis. Oleh karena itu, harga saham di pasar umumnya sudah menggambarkan segala informasi yang melekat di dalamnya sesuai dengan teori Fama (1970).

Tandelilin (2017: 224) mengatakan bahwa kondisi pasar di mana harga saham adalah cerminan seluruh informasi yang tersedia disebut dengan pasar efisien. Informasi bisa berbentuk informasi masa 
lalu (contoh: laporan keuangan), informasi saat ini (contoh: rencana kenaikan laba dan rencana pembagian dividen), hingga informasi bersifat opini/pendapat rasional yang beredar di pasar yang bisa memengaruhi harga (contoh: rekomendasi analis perusahaan efek).

Bebarapa penelitian mengemukakan bahwa terdapat bukti penyimpangan pasar efisien yang disebut anomali pasar, yaitu kondisi di mana harga saham tidak mencerminkan informasi yang tersedia. Jones (1997:267) menyebutkan bahwa dalam anomali pasar ialah suatu strategi atau teknik yang bertentangan dengan teori efisiensi pasar. Hal tersebut menyebabkan pasar modal tidak lagi bergerak secara acak, tetapi memiliki pola dan struktur yang terjadi berulang-ulang pada suatu periode waktu. Menurut Reilly (dalam Fitriyani \& Sari, 2013), penyebab anomali pasar modal terbagi menjadi 3 yaitu: (1) Struktur pasar yang tidak sempurna, (2) Peyimpangan perilaku investor di pasar dan hal tersebut dilakukan oleh banyak investor sehingga mampu memengaruhi harga saham di pasar, (3) Acuan teori pasar modal yang digunakan tidak tepat sehingga memungkinkan terjadi kesalahan dalam penilaian suatu pasar modal. Gumanti \& Utami (2002) menyebutkan bahwa anomali pasar terbagi menjadi empat klasifikasi yaitu: (1) anomali perusahaan, (2) anomali musiman, (3) anomali peristiwa/kejaidian, (4) anomali akuntansi.

Anomali yang diangkat dalam penelitian ini adalah bagian dari anomali musiman yaitu Sell in May and Go Away (SMGA). Sering dikenal juga dengan istilah Hallowen Effect atau October Effect karena pada penelitian Dichtl \& Drobetz (2013) mengatakan bahwa Sell in May and Go Away (SMGA) dan Hallowen Effect merujuk pada anomali yang sama. Menurut penelitian Haggard \& Witte (2010) serta tulisan Atmaja (2015), SMGA merupakan suatu strategi yang berasal dari Amerika, di mana investor percaya bahwa imbal hasil saham periode Mei - Oktober cenderung lebih rendah daripada November - April. Mengacu pada buku Stock Trader Almanac karya Hirsch (2015:83), periode tersebut disebut dengan istilah worst period dan best period. Strategi SMGA menyarankan investor melakukan aksi jual pada bulan Mei, kemudian memegang dana cash atau menginvestasikan uangnya pada instrumen pasar uang, kemudian masuk kembali ke bursa saham pada awal November.

Menurut Hayes (2019), September dan Oktober merupakan bulan paling buruk di Bursa Saham Amerika. Return pada bulan September untuk indeks S\&P's 500 dari 1950 adalah -0,65\% sedangkan di bulan Desember mampu memberikan return sebesar 1,59\%. Jika melihat dari sejarah, bulan Oktober adalah bulan di mana banyak terjadi peristiwa kejatuhan bursa saham Amerika, seperti Stock Market Crash sebesar 43\% pada 1973 dan 30\% pada 1987, hingga kebangkrutan perusahaan investasi terbesar, Lehman Brothers pada 2008 yang turut berimbas pada negara lain.

Penelitian ini bertujuan meneliti anomali musiman Sell in May and Go Away di dua bursa saham Asia Tenggara yakni Bursa Efek Indonesia dan Bursa Malaysia. Kedua bursa tersebut dipilih karena masuk dalam 5 bursa saham yang memiliki kapitalisasi terbesar di Asia Tenggara. Pengambilan populasi ini dikarenakan Indonesia dan Malaysia adalah negara berkembang tujuan investasi dari investor asing. Tahun 2017 investasi langsung ke Asia Tenggara mengukir rekor baru di level US\$ 137 miliar dari sebelumnya US\$ 123 miliar Tahun 2016. Malaysia, Indonesia dan Singapura, menyumbang 72\% dari arus masuk investasi asing langsung tersebut (Triatmojo, 2019).

Menurut Annual Report tahun 2018 yang dikeluarkan masing-masing Bursa Efek Indonesia (BEI) dan Bursa Malaysia selaku penyelenggara perdagangan efek, terdapat proporsi investor asing yang cukup besar atas kepemilikan saham yang beredar. Bursa Efek Indonesia mencatatkan 45,69\% proporsi investasi pasar modal berasal dari asing, sedangkan di Malaysia tercatat sebesar 24\%. Besarnya proporsi dana asing yang ada di bursa saham Asia Tenggara memungkinkan reaksi investor asing akan suatu hal mampu memengaruhi pergerakan harga. Dalam pasar modal terdapat istilah net foreign buy dan net foreign sell. Ini adalah suatu kondisi di mana dana asing dianggap banyak masuk (capital inflow) atau keluar (capital outflow) dari suatu bursa saham. Saat terjadi net foreign buy atau dana asing masuk lebih besar daripada dana keluar, maka harga saham akan cenderung bergerak positif. Berbading terbalik, saat terjadi net foreign sell yang berarti lebih banyak dana asing keluar daripada masuk, maka kenerja bursa akan melemah (Agustina, 2018). Argumen ini diperkuat dengan data akumulasi net foreign activity pada Bursa Efek Indonesia dan Malaysia sebagai berikut. 


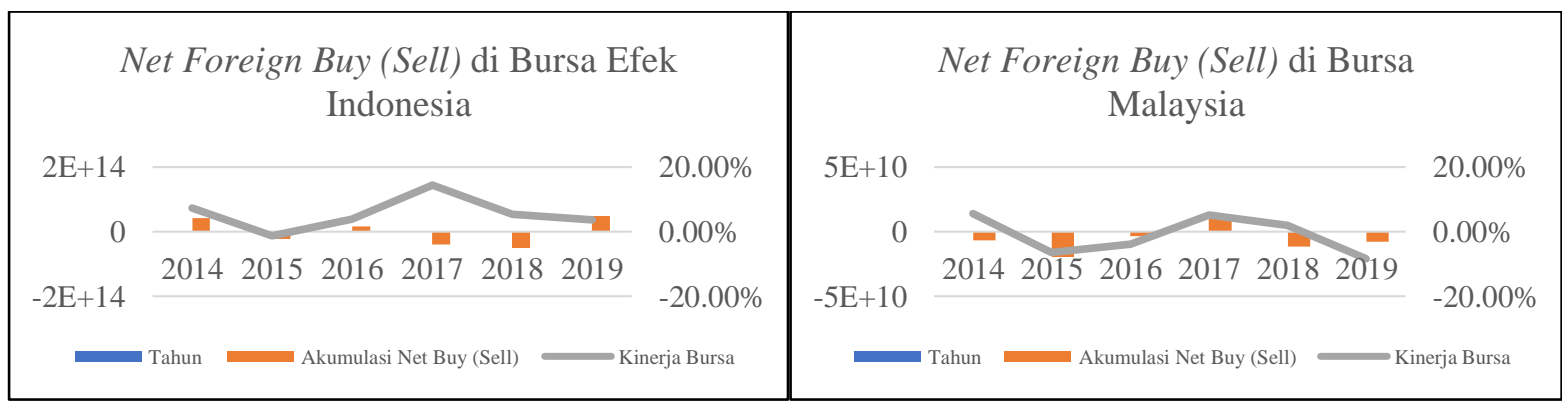

Sumber : Investing.com (2019, data diolah)

Gambar 1. NET FOREIGN ACT BURSA EFEK INDONESIA DAN MALAYSIA

Gambar 1 dapat dilihat saat terjadi net foreign buy, kinerja harga saham akan positif seperti yang terjadi pada bursa saham Malaysia pada 2016 ke 2017 dan di Bursa Saham Indonesia pada 2015 ke 2016. Begitu pula saat terjadi net foreign sell, kinerja bursa berbalik negatif seperti di Malaysia pada 2015, 2016 dan 2019, serta di Indonesia Tahun 2015, 2018 dan 2019. Data tersebut menjelaskan bahwa net foreign activity hampir selalu berbanding lurus dengan kinerja bursa, mengindikasikan bahwa keputusan investasi asing banyak diikuti oleh investor lokal hingga menyebabkan kinerja bursa terpengaruh secara keseluruhan. Hal ini mendukung penelitian Frensidy (2008) tentang optimisme investor asing yang mampu memengaruhi investor lokal karena dianggap memiliki modal yang besar, serta analisis fundamental dan informasi yang lebih baik.

Bersama dengan perkembangan teknologi, pasar modal di seluruh dunia juga ikut bertumbuh dengan pesat, menyebabkan batas wilayah dan negara semakin tipis. Hal ini membuat bursa saham di seluruh dunia saling memengaruhi dibanyak aspek (Frensidy, 2008). Selayaknya sentimen pasar luar negeri yang memengaruhi bursa lokal, strategi Sell in May and Go Away (SMGA) yang berasal dari Eropa dan Amerika akan mampu memberikan pengaruh pada pasar modal negara lain. Bouman \& Jacobsen (2002) meneliti tentang anomali SMGA dan terbukti terjadi di 36 dari 37 negara yang diteliti. Lean (2011) menunjukkan bahwa di Singapura, Malaysia, Cina, Jepang dan India, anomali ini terbukti keberadaannya.

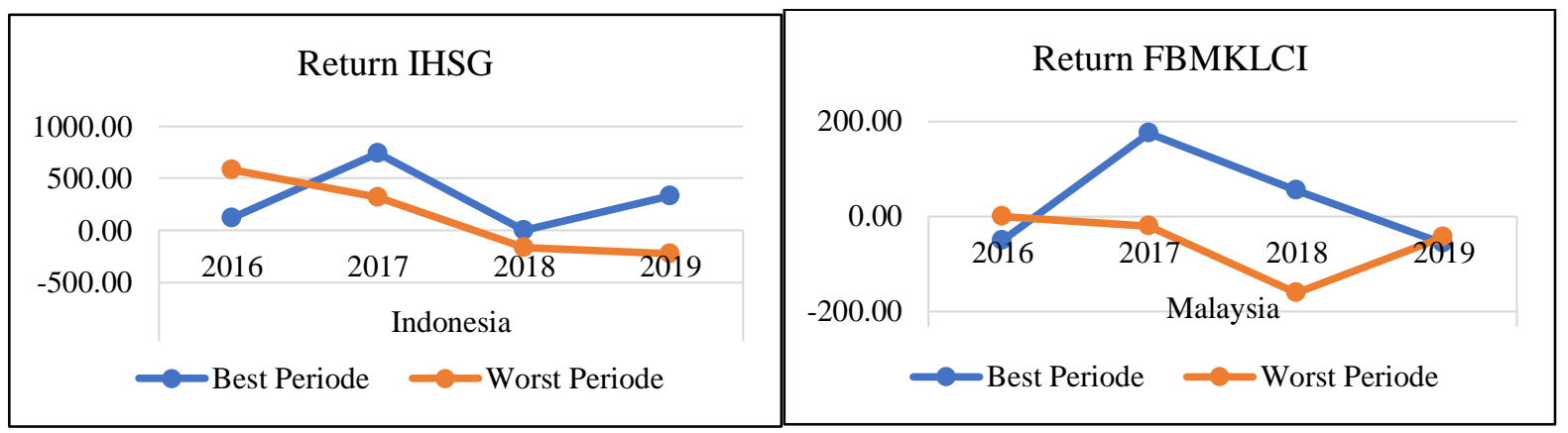

Sumber : Investing.com (2019, data diolah)

\section{Gambar 2: IMBAL HASIL KLCI DAN IHSG PERIODE 2016-2019}

Gambar 2 adalah grafik imbal hasil Indeks Harga Saham Gabungan (IHSG) sebagai indeks utama Bursa Efek Indonesia, serta grafik imbal hasil Kuala Lumpur Composite Index (KLCI) sebagai indeks utama Bursa Malaysia. Periode penelitian dibagi menjadi 2 yaitu periode SMGA (Mei - Oktober) atau worst periode dan periode Non-SMGA (November - April) atau best period. Baik di IHSG maupun KLCI, average price bulan Mei selalu dicatatkan menurun pada 3 tahun dari 4 tahun pengamatan meskipun tidak terjadi secara berturut-turut. Kemudian dari grafik return, baik pada IHSG maupun KLCI, terlihat bahwa pada worst period sering kali return realisasi yang didapatkan lebih rendah daripada saat best periode. Dari data di atas, dapat ditarik suatu asumsi bahwa pada worst period, imbal hasil yang didapatkan jauh lebih kecil daripada best periode, yang mengkonfirmasi keberadaan anomali SMGA baik di bursa saham Indonesa maupun Malaysia. 
Penelitian terdahulu mengenai anomali Sell in May and Go Away telah menunjukkan berbagai hasil yang beragam dengan berbagai bursa saham di seluruh dunia sebagai sampel pengujian. Namun masih sangat sedikit penelitian tentang anomali SMGA yang dilakukan di pasar modal Asia Tenggara. Padahal Asia Tenggara berisi negara-negara dengan bursa saham potensial karena menjadi tujuan investasi (Triatmojo, 2019). Adanya foreign activity yang besar pada pasar modal suatu negara memberikan hubungan yang signifikan terhadap return saham, yang berarti dengan adanya kenaikan pada dalam foreign flows akan berpengaruh pula pada performa pasar modal karena cenderung dipengaruhi oleh investor asing (Oro, 2013). Tujuan dari penelitian ini adalah mengkonfirmasi anomali SMGA pada suatu bursa saham. Hal tersebut penting untuk dilakukan agar investor tidak terjebak pada informasi yang keliru hingga dapat menyebabkan kerugian. Diharapkan investor mampu mengelola infomasi dan anomali yang ada dan memanfaatkannya menjadi suatu peluang untuk memeroleh abnormal return. Kemudian dapat pula dijadikan acuan regulator sebagai sarana memperkuat kinerja pasar modal di Indonesia dan Malaysia. Berdasarkan fenomena tersebut, Bursa Efek Indonesia dan Bursa Malaysia digunakan sebagai objek penelitian fenomena Sell in May and Go Away selama periode 2017-2019.

\section{KAJIAN PUSTAKA DAN PENGEMBANGAN HIPOTESIS}

\section{Contagion Effect}

Contagion effect (efek penularan) ialah kondisi saat krisis finansial di suatu tempat dipicu oleh kejadian di tempat lain (Yang \& Lim, 2004). Fenomena yang paling sering ditemui adalah krisis lembaga perbankan yang memengaruhi lembaga perbankan lainnya, atau stock market crush suatu negara memengaruhi bursa saham negara lainnya (Laeven \& Valencia, 2013). Hal ini disebabkan oleh perkembangan globalisasi dan perdagangan bebas yang menyebabkan kondisi perekonomian sangat terhubung. Saat suatu negara mengalami krisis, akan terjadi efek domino di mana krisis tersebut akan memengaruhi negara lain, terutama yang sering melakukan transaksi perdagangan dengan negara tersebut. Perilaku investor dapat pula menyebabkan efek penularan. Tindakan kolektif akibat ketidakpercayaan investor akan mampu menyebar dengan cepat karena investor di berbagai dunia saling terhubung dan berbagi informasi yang sama. Informasi baru akan mampu memicu signal yang mengubah arah ekspektasi investor (Eichengreen et al., 1996).

\section{Event Study}

Event study ialah studi pengamatan reaksi pasar akibat suatu peristiwa yang informasinya terpublikasi menjadi sebuah pengumuman. Event study dapat dijadikan acuan untuk mencari tahu kandungan informasi dalam sebuah publikasi serta berguna untuk menilai efisiensi pasar bentuk setengah kuat (Hartono, 2016:643). Penelitian event study berhubungan dengan secepat apa sebuah informasi yang terpublikasi ke pasar bisa berpengaruh pada naik ataupun turunnya harga sekuritas (Tandelilin, 2017:223). Reaksi atas suatu pengumuman dapat diuji menggunakan dampak kandungan informasinya. Pengumuman yang mengandung informasi akan menyebabkan pasar bereaksi dan ditunjukkan dengan perubahan harga dari suatu emiten (Hartono, 2016:643).

\section{Efisiensi Pasar}

Menurut Tandelilin (2017:224), pasar efisien merupakan pasar yang mencerminkan informasi harga saham pada kondisi yang sebenarnya. Sedangkan pasar tidak efesien ialah pasar yang tidak mencerminkan harga suatu saham pada kondisi yang sebenarnya dan harga saham tersebut secara signifikan dipengaruhi oleh perilaku investor. Konsep tentang pasar efisien dipaparkan oleh Fama (1970), menyatakan bahwa harga saham pada suatu pasar yang efisien tercermin secara penuh (fully reflect) sesuai dengan informasi yang beredar. Efisiensi dan kandungan informasi pasar adalah hal yang sangat berkaitan. Efisiensi pasar dapat diuji dengan melihat reaksi pasar terkait informasi dan kandungan informasi tersebut. Reaksi tersebut umumnya diukur menggunakan rumus abnormal return (Hartono, 2016:643).

\section{Anomali Pasar}

Anomali merupakan suatu teknik atau strategi yang melawan konsep teori pasar efisien (Jones, 1997:267). Anomali pasar modal berkembang menjadi suatu konsep yang menyatakan bahwa harga- 
harga saham yang beredar di pasar tidak menggambarkan kondisi yang sebenarnya dari saham suatu emiten. Penelitian ini membahas anomali kalender di mana teori yang beredar adalah harga saham bergerak fluktiatif, bisa cenderung naik atau turun pada bulan atau periode tertentu setiap tahunnya dan terjadi berulang-ulang. Pada kondisi bursa saham yang mengalami anomali, investor akan berpotensi mendapatkan imbal hasil tak normal (abnormal return) karena potensi return bisa diprediksi. Penyebab terjadinya anomali yaitu: (1) Tidak sempurnanya struktur pada pasar meskipun pada aplikasinya tidak ada pasar dengan kondisi yang sempurna. (2) Adanya beberapa penyimpangan perilaku investor di pasar dengan skala yang cukup untuk memengaruhi pergerakan pasar. Perilaku menunjukkan bila hanya berasal dari satu individu memang tidak mampu memengaruhi pasar, tetapi jika penyimpangan perilaku tersebut terjadi dalam jumlah besar atau melibatkan banyak investor maka dampak yang imbul akan terakumulasi sehingga meningkatkan dampaknya. (3) Adanya ketidaktepatan acuan teori pasar modal sehingga memberi ruang dan memungkinkan penyimpangan dalam penilaian pasar modal (Fitriyani \& Sari, 2013).

\section{Sell in May and Go Away}

Anomali Sell in May and Go Away (SMGA) yang dikenal juga dengan istilah October Effect dan atau Hellowen Effect adalah adalah sebuah teori yang menyatakan bahwa harga saham akan bergerak negatif pada periode Mei hingga Oktober setiap tahunnya. Hal tersebut akan mengakibatkan investor mengalami kerugian karena kondisi pasar. Kejadian tersebut akan menimbulkan kecemasan dan ketakutan pada periode waktu Mei hingga Oktober (Haggard \& Witte, 2010). Selain itu, Hayes (2019) menjelaskan bahwa dari sisi sejarah, beberapa peristiwa masa lalu pernah terjadi kehancuran pasar saham di periode tersebut. Fenomena itu sering disebut dengan istilah "Halloween Effect". Peristiwa tersebut antara lain Black Monday, Black Tuesday, dan Black Thursday yang terjadi pada bulan Oktober 1929. Di Amerika dan Eropa, anomali ini semakin diperkuat dengan periode yang bersamaan dengan libur musim panas, di mana banyak investor menjual saham mereka karena kebutuhan akan uang tunai demi kegiatan konsumsi yang meningkat selama musim panas (Wicaksana \& Nadia, 2018).

\section{Abnormal Return}

Return tak normal (abnormal return) adalah selisih antara return sesungguhnya (actual return) dengan return yang diharapkan (expected return) pada suatu sekuritas (Hartono, 2016:667). Formulanya ialah:

$A R_{i, t}=R_{i, t}-E\left[R_{i, t}\right]$

Keterangan:

$A R_{i, t} \quad$ : Abnormal return sekuritas ke-i pada hari ke-t

$R_{i, t} \quad$ : Actual return sekuritas ke-i pada hari ke-t

$E\left[R_{i, t}\right]:$ Expected return sekuritas ke-i pada hari ke-t

\section{Hubungan antar Variabel}

Market anomaly (anomali pasar) ialah suatu teknik atau strategi yang berlawanan dengan konsep pasar efisien (Jones, 1997:267). Pasar yang mengalami fenomena anomali Sell in May and Go Away (SMGA) membuat investor berpotensi memeroleh imbal hasil tak normal (abnormal return) yang lebih tinggi pada periode di luar SMGA yaitu November - April karena potensi return dapat diprediksi (Fitriyani \& Sari, 2013). Secara teori, imbal hasil periode SMGA yaitu Mei - Oktober lebih rendah daripada periode lainnya yakni November - April. Abnormal return merupakan selisih antara tingkat keuntungan yang telah diperoleh dengan tingkat keuntungan yang diharapkan (Husnan, 2002). Dari data investing.com yang telah diolah pada gambar 2, rata-rata imbal hasil pada Indeks Harga Saham Gabungan (IHSG) sebagai indeks utama Bursa Efek Indonesia secara historis menunjukkan bahwa return pada best period lebih tinggi dari worst period selama 3 tahun pengamatan. Hayati et al. (2020) meneliti Sell in May and Go Away di Bursa Efek Indonesia menggunakan indeks Harga Saham Gabungan (IHSG), menemukan fakta bahwa meskipun tidak konsisten, rata-rata imbal hasil cenderung lebih tinggi pada periode November-April (best period). 
Laila Marta Zarika \& R.A. Sista Paramita. Analisis Sell in May and Go Away di Bursa Efek Indonesia dan Malaysia Periode 2017-2019

H1: Ada perbedaan abnormal return antara periode Sell in May and Go Away dengan periode lainnya pada Bursa Efek Indonesia periode 2017-2019.

Pada Bursa Malaysia, data investing.com yang telah diolah pada gambar 2 menunjukkan selama tiga dari empat tahun pengamatan, rata-rata imbal hasil pada best period lebih tinggi dari worst period, meskipun pada 2019 gap antara dua periode tersebut sangat tipis. Lean (2011) meneliti anomali Sell in May and Go Away di beberapa pasar modal Asia dan menemukan bahwa anomali SMGA ditemukan di pasar modal Singapura dan Malaysia, selaku sampel untuk wilayah Asia Tenggara. Pada pasar modal yang terindikasi mengalami anomali SMGA, mengalami imbal hasil (return) pada worst period lebih rendah dibandingkan dengan best period.

H2: Ada perbedaan abnormal return antara periode Sell in May and Go Away dengan periode lainnya pada Bursa Malaysia tahun 2017-2019.

\section{METODE PENELITIAN}

Jenis penelitian ini adalah penelitian komparatif yang memakai variabel mandiri (satu variabel) tetapi berada pada populasi dan sampel yang berbeda, serta periode waktu yang berbeda pula (Sugiyono, 2017:117), dengan tujuan menganalisis perbedaan abnormal return pada Bursa Efek Indonesia dan Bursa Malaysia terkait fenomena Sell in May and Go Away periode 2017-2019. Penelitian ini menggunakan metode studi peristiwa (event study) yang bertujuan menganalisis reaksi pada suatu peristiwa atau pengumuman tertentu yang diduga memiliki kandungan informasi yang akan memengaruhi reaksi pasar serta berguna untuk menilai efisiensi pasar bentuk setengah kuat (Hartono, 2016: 643).

Populasi dari penelitian ini mencakup 61 emiten yang terdaftar di indeks LQ45 Bursa Efek Indonesia dan 30 emiten yang terdaftar di indeks FBMKLCI Bursa Malaysia. Indeks LQ45 adalah indeks di Bursa Efek Indonesia, terdiri atas 45 saham emiten dengan kondisi keuangan yang baik dan memiliki kapitalisasi, nilai transaksi serta nilai transaksi yang tinggi. Sedangkan FTSE Bursa Malaysia KLCI (FBMKLCI) adalah bagian dari FTSE Bursa Malaysia Index Series, yang terdiri atas 30 perusahaan yang representatif, likuid dan transparan. Perusahaan yang masuk dalam indeks ini adalah perusahaan dengan kapitalisasi pasar terbesar di papan utama Bursa Malaysia. Total populasi adalah 91 emiten yang terdaftar selama periode pengamatan 2017-2019. Dari populasi tersebut dilakukan proses pemilihan sampel dengan acuan non-probability sampling serta menggunakan metode purposive sampling dengan kriteria sebagai berikut: (1) Emiten terdaftar di indeks LQ45 dan FBMKLCI pada periode pengamatan yakni tahun 2017-2019. (2) Emiten yang tidak melakukan corporat action selama periode penelitian dalam bentuk buy back, right issue, dan stock split pada periode pengamatan. Setelah dilakukan penyaringan dengan kriteria tersebut, tersisa 22 emiten di indeks LQ45 dan 22 emiten di indeks FBMKLCI. Total keseluruhan sampel adalah 44 emiten yang sesuai dengan kriteria.

Analisis data meliputi descriptive statistics, uji normalitas Kolmogorov Smirnov Test, serta uji hipotesis dengan uji beda Paired Sample T-Test untuk membuktikan ada atau tidaknya perbedaan abnormal return pada best period dan worst period. Hasil pengujian dianalisis dengan level of significance $(\alpha)$, yaitu sebesar $5 \%$ dengan derajat kebebasan (df) sebesar $n-1$. Apabila nilai signifikansi $<0,05$ maka $\mathrm{H} 1$ dan $\mathrm{H} 2$ diterima, berarti terdapat perbedaan abnormal return antara best period dan worst period. Jika nilai signifikansi $>0,05$ maka $\mathrm{H} 1$ dan $\mathrm{H} 2$ ditolak, artinya tidak terdapat perbedaan abnormal return antara best period dan worst period selama periode pengamatan.

\section{HASIL DAN PEMBAHASAN}

\section{Statistik Deskriptif}

Tabel 1 menunjukkan hasil pengujian statistik deskriptif dari 22 emiten indeks LQ45 dan 22 emiten indeks FBMKLCI. Data sudah diolah terlebih dahulu dari rata-rata harga saham per emiten setiap bulan, kemudian dihitung sehingga memeroleh data abnormal return setiap emiten dan di kelompokan pada masing-masing indeks menjadi dua periode yakni periode SMGA dan non-SMGA. 
Tahun 2017, indeks LQ45 dan FBMKLCI mencatatkan rata-rata imbal hasil periode non-SMGA sebesar minus 0,0116 yang mana jauh lebih kecil daripada imbal hasil periode SMGA sebesar 0,0022. Hal tersebut menunjukkan bahwa investor cenderung memeroleh keuntungan pada saat periode SMGA yakni bulan Mei-Oktober. Tahun 2018, indeks LQ45 dan FBMKLCI memiliki rata-rata imbal hasil untuk periode SMGA sebesar minus 0,0113 dan 0,0044 untuk periode non-SMGA. Hal tersebut mengindikasikan bahwa investor cenderung mendapatkan abnormal return pada periode non-SMGA yakni bulan November-April sesuai dengan besarnya selisih return yang diperoleh atas return ekspektasi. Tahun 2019, indeks LQ45 dan FBMKLCI memeroleh return periode SMGA sebesar minus 0,0025 dan periode non-SMGA sebesar 0,0118. Pada situasi tersebut, investor cenderung mendapatkan abnormal return lebih tinggi pada periode non-SMGA. Dari 6 pasang pengujian statistik deskriptif, hanya tahun 2017 yang tidak memenuhi hipotesis yang diajukan karena imbal hasil periode SMGA lebih tinggi daripada non-SMGA.

Tabel 1.

\section{DESCRIPTIVE STATISTICS}

\begin{tabular}{lrrrrr}
\hline \multicolumn{1}{c}{ Variabel } & N & Minimum & Maximum & \multicolumn{1}{c}{ Mean } & Std. Deviation \\
\hline SMGA LQ45 17 & 6 & $-0,0496$ & 0,0358 & 0,0022 & 0,0288 \\
non SMGA LQ45 17 & 6 & $-0,0288$ & 0,0140 & $-0,0116$ & 0,0178 \\
SMGA LQ45 18 & 6 & $-0,0474$ & 0,0148 & $-0,0113$ & 0,0287 \\
non SMGA LQ45 18 & 6 & $-0,0517$ & 0,0712 & 0,0044 & 0,0422 \\
SMGA LQ45 19 & 6 & $-0,0176$ & 0,0154 & $-0,0025$ & 0,0128 \\
non SMGA LQ45 19 & 6 & $-0,0361$ & 0,0476 & 0,0118 & 0,0301 \\
SMGA FBMKLCI 17 & 6 & $-0,0496$ & 0,0358 & 0,0022 & 0,0288 \\
non SMGA FBMKLCI 17 & 6 & $-0,0288$ & 0,0140 & $-0,0116$ & 0,0178 \\
SMGA FBMKLCI 18 & 6 & $-0,0474$ & 0,0148 & $-0,0113$ & 0,0287 \\
non SMGA FBMKLCI 18 & 6 & $-0,0517$ & 0,0712 & 0,0044 & 0,0422 \\
SMGA FBMKLCI 19 & 6 & $-0,0176$ & 0,0154 & $-0,0025$ & 0,0128 \\
non SMGA FBMKLCI 19 & 6 & $-0,0361$ & 0,0476 & 0,0118 & 0,0301 \\
\hline Sumber Data Dion
\end{tabular}

Sumber: Data Diolah (SPSS, 2020)

\section{Uji Normalitas}

Tabel 2.

HASIL UJI ONE-SAMPLE KOLMOGOROV-SMIRNOV TEST INDEKS LQ45 DAN FBMKLCI

\begin{tabular}{|c|c|c|c|c|c|c|c|}
\hline \multirow{2}{*}{ IHSG } & \multicolumn{2}{|c|}{ Nilai Signifikansi } & \multirow{2}{*}{$\begin{array}{c}\text { Hasil Uji } \\
\text { Normalitas }\end{array}$} & \multirow{2}{*}{ KLCI } & \multicolumn{2}{|c|}{ Nilai Signifikansi } & \multirow{2}{*}{$\begin{array}{c}\text { Hasil Uji } \\
\text { Normalitas }\end{array}$} \\
\hline & SMGA & non-SMGA & & & SMGA & non-SMGA & \\
\hline 2017 & 0,2 & 0,2 & Normal & 2017 & 0,2 & 0,2 & Normal \\
\hline 2018 & 0,129 & 0,2 & Normal & 2018 & 0,129 & 0,2 & Normal \\
\hline 2019 & 0,2 & 0,2 & Normal & 2019 & 0,2 & 0,2 & Normal \\
\hline
\end{tabular}

Sumber: Data Diolah (SPSS, 2020)

Uji normalitas menggunakan uji one-sample Kolmogorov Smirnov test untuk mengkonfirmasi apakah data terdistribusi normal atau tidak. Pada tabel uji Kolmogorov Smirnov, normalitas ditentukan menggunakan besarnya nilai signifikansi. Pengambilan keputusan didasarkan atas angka probabilitas signifikan $\alpha=5 \%$. Hasil dari uji normalitas Tabel 2 menunjukkan bahwa semua data terdistribusi normal karena nilai sigifikansi $>0,05$.

\section{Uji Hipotesis}

Tabel 3 menunjukkan nilai signifikansi pada 6 pasang periode pengamatan. Pair 1, 2 dan 3 adalah hasil analisis untuk indeks LQ45 Bursa Efek Indonesia. Nilai signifikansi pada semua periode pengamatan adalah $>0,05$ sehingga hipotesis 1 ditolak. Artinya, tidak ada perbedaan abnormal return antara periode SMGA dan non-SMGA di Bursa Efek Indonesia pada periode 2017-2019. Pair 4, 5 dan 6 adalah hasil analisis untuk indeks FBMKLCI Bursa Malaysia. Nilai signifikansi pada semua periode 
Laila Marta Zarika \& R.A. Sista Paramita. Analisis Sell in May and Go Away di Bursa Efek Indonesia dan Malaysia Periode 2017-2019

pengamatan adalah $>0,05$ sehingga hipetesis 2 ditolak. Artinya, tidak ada perbedaan abnormal return antara periode SMGA dan non-SMGA di Bursa Malaysia selama periode pengamatan 2017-2019.

Tabel 3.

HASIL UJI PAIRED SAMPLE T-TEST INDEKS LQ45 DAN FBMKLCI TAHUN 2017-2019

\begin{tabular}{llllll}
\hline & & T & df & Sig. & Keterangan \\
\hline Pair 1 & SMGA LQ45 17 - non SMGA LQ45 17 & 1,084 & 5 & 0,328 & Tidak Beda \\
Pair 2 & SMGA LQ45 18 - non SMGA LQ45 18 & $-0,781$ & 5 & 0,470 & Tidak Beda \\
Pair 3 & SMGA LQ45 19 - non SMGA LQ45 19 & $-1,005$ & 5 & 0,361 & Tidak Beda \\
Pair 4 & SMGA FBMKLCI 17 - non SMGA FBMKLCI 17 & 1,084 & 5 & 0,328 & Tidak Beda \\
Pair 5 & SMGA FBMKLCI 18 - non SMGA FBMKLCI 18 & $-0,781$ & 5 & 0,470 & Tidak Beda \\
Pair 6 & SMGA FBMKLCI 19 - non SMGA FBMKLCI 19 & $-1,005$ & 5 & 0,361 & Tidak Beda \\
\hline
\end{tabular}

Sumber: Data Diolah (SPSS, 2020)

\section{Pembahasan}

Tidak ada perbedaan abnormal return mengindikasikan bahwa fenomena Sell in and Go Away tidak terjadi baik di Indonesia dan Malaysia selama periode pengamatan. Fakta ini menunjukkan bahwa pasar modal di dua negara tersebut tidak bereaksi positif terhadap fenomena Sell in May and Go Away (SMGA). Hal tersebut disebabkan investor beranggapan bahwa periode SMGA bukan suatu periode penting. Penyebab dari fenomena ini salah satunya adalah bahwa di Eropa dan Amerika, periode SMGA ini bersamaan dengan musim panas. Libur musim panas yang panjang akan meningkatkan kebutuhan fresh money sehingga banyak investor menjual sahamnya untu memenuhi kebutuhan konsumsi. Asia Tenggara, khususnya Malaysia dan Indonesia adalah negara tropis dua musim, sehingga budaya konsumsi periode Mei-Oktober ini tidak menunjukkan peningkatan yang berarti dibandingkan tingkat konsumsi di Eropa dan Amerika. Sell in May and Go Away sebagai suatu strategi yang banyak disarankan broker juga tidak cocok diterapkan di Bursa Efek Indonesia dan Malaysia karena abnormal return di indeks LQ45 dan FBMKLCI tidak berbeda dengan periode lainnya selama periode pengamatan.

Sell in May and Go Away tidak terjadi baik di Indonesia dan Malaysia pada periode 2017-2019 kemungkinan disebabkan oleh jumlah proporsi kepemilikan saham oleh investor lokal di masingmasing bursa sudah cukup tinggi. Pada hipotesis awal, meskipun proporsi investor asing lebih kecil dari pada investor lokal, pergerakan investor asing akan tetap diantispasi dan diikuti karena stigma bahwa investor asing memiliki modal yang besar, akses informasi lebih luas dan daya analisis yang lebih baik Frensidy (2008). Selain hal tersebut, meskipun fenomena bulanan Sell in May and Go Away ini sudah menjadi budaya dan dipercayai banyak investor, tampaknya strategi ini sudah tidak populer untuk diterapkan dalam pengambilan keputusan investasi. Penelitian Dichtl \& Drobetz (2014) juga menyatakan jika Sell in May and Go Away telah melemah dari tahun ke tahun, serta penelitian Wicaksana \& Nadia (2018) yang menyatakan bahwa Sell in May and Go Away tidak terjadi di Bursa Efek Indonesia. Begitu juga dengan hasil penelitian Zhang \& Jacobsen (2013)yang mengatakan bahwa fenomena anomali bulanan ini hanyalah ilusi investor semata sebagai hasil dari sejarah buruk masa lalu.

Contagion effect menyatakan bahwa fenomena di suatu lokasi dapat memengaruhi lokasi yang lainnya (Yang \& Lim, 2004). Fenomena yang dimaksud tidak terbatas pada kejadian-kejadian seperti krisis suatu lembaga keuangan, tetapi juga mencakup perilaku investor. Indeks Amerika Serikat Standard\&Poor500 mencatatkan bahwa imbal hasil periode May-Oktober terbukti lebih rendah 4,7\% dibandingkan periode November-April selama periode 1991-2017 (Scoot, 2019), sedangkan di Eropa, best period November-April memberikan imbal hasil 2,4\% lebih tinggi daripada worst period. Penelitian tersebut dilakukan pada 10 indeks di wilayah Eropa dan negara-negara Nordik (Carrazedo et al., 2016). Hal ini mengindikasikan bahwa efek kontijensi tidak terjadi pada skema anomali ini karena baik di Indonesia dan Malaysia, perbedaan return antara dua periode tersebut tidak dapat dibuktikan. 
Hartono (2016: 643) menyatakan bahwa event study digunakan untuk menguji reaksi pasar dari suatu informasi. Metode ini dapat digunakan untuk mengukur pasar efisien bentuk setengah kuat (semistrong form). Jika suatu informasi menimbulkan reaksi pasar yang cepat, maka pasar dapat dikatakan efisien. Sell in May and Go Away sebagai suatu strategi, fenomena dan budaya investasi pasar modal global tentu diketahui oleh semua broker dan akan menjadi suatu informasi bagi investor dalam bentuk brokorage advice. Fakta bahwa pasar tidak bereaksi atas informasi tersebut menunjukkan bahwa bentuk pasar modal di Indonesia dan Mayasia bukanlah pasar efisien setengah kuat (semistrong form) dan lebih cenderung ke arah pasar efisien bentuk lemah (weak form).

\section{KESIMPULAN}

Berlandaskan pada hasil penelitian dan pembahasan, dideteksi tidak ada perbedaan imbal hasil pada periode bulan Sell in May and Go Away dengan non-Sell in May and Go Away di Bursa Efek Indonesia dan Malaysia periode 2017-2019. Sehingga disimpulkan bahwa fenomena tersebut tidak terjadi di Bursa Efek Indonesia dan Malaysia selama periode penelitian. Meskipun pada grafik imbal hasil IHSG dan KLCI terlihat ada fenomena SMGA, hasil pengujian abnormal return menyatakan anomali tersebut tidak ditemukan pada Bursa Efek Indonesia dan Bursa Malaysia periode 2017-2019. Penelitian ini menggunakan sampel seluruh emiten yang terdaftar dan memenuhi sarat pengambilan sampel, baik emiten di indeks LQ45 maupun FBMKLCI. Indeks yang digunakan adalah masingmasing indeks dengan anggota perusahaan-perusahaan terbaik, berkapitalisasi terbesar dan terkategori sebagai index mover artinya perusahaan-perusahaan yang menggerakan indeks tertentu.

Implikasi secara teoritis dan praktis dari penelitian ini, investor sebaiknya melakukan analisis pada keputusan investasinya yakni dengan memahami dan mengantisipasi berbagai kerjadian dengan informasi positif dan negatif. Selain itu, agar dapat merealisasikan harapan atas imbal hasil investasi, investor sebaiknya tidak hanya fokus pada peristiwa dan atau strategi tertentu, tetapi juga mengantisipasi peristiwa lainnya yang dapat memengaruhi pergerakan harga saham, serta tetap memperhatikan kondisi ekonomi makro dan mikro.

Penelitian ini masih memiliki keterbatasan antara lain pendeknya rentang periode pengamatan, sempitnya cakupan negara yang diteliti dan hanya menggunakan satu variabel penelitian yakni abnormal return. Untuk penelitian selanjutnya, disarankan menggunakan tahun pengamatan yang lebih panjang dan menambah variabel seperti trading value activity dan trading volume activity pada penelitian selanjutnya. Selain itu, memperluas cakupan wilayah penelitian seperti satu regional atau satu benua akan membuat penelitian tentang fenomena anomali musiman Sell in May and Go Away menjadi lebih baik lagi kedepannya.

\section{DAFTAR PUSTAKA}

Agustina, N. F. (2018). Analisis Hubungan Saling Ketergantungan Antara Net Investment Institusi Asing Dengan Return LQ45. Jurnal Illmiah Mahasiswa FEB Universitas Brawijaya, 6(2). jimfeb.ub.ac.id

Atmaja, L. S. (2015, May 27). Wabah Halloween Effect di Bursa Efek Indonesia. Kontan.co.id. (https://kolom.kontan.co.id/news/346/Wabah-Halloween-Effect-di-Bursa-Efek-Indonesia, diakses pada 12 September 2019)

Bouman, S., \& Jacobsen, B. (2002). The halloween indicator, "sell in May and go away": Another puzzle. American Economic Review, 92(5), 1618-1635. https://doi.org/10.1257/000282802762024683

Carrazedo, T., Curto, J. D., \& Oliveira, L. (2016). The Halloween effect in European sectors. Research in International Business and Finance, 37, 489-500. https://doi.org/10.1016/j.ribaf.2016.01.003 
Laila Marta Zarika \& R.A. Sista Paramita. Analisis Sell in May and Go Away di Bursa Efek Indonesia dan Malaysia Periode 2017-2019

Dichtl, H., \& Drobetz, W. (2013). Are stock markets really so inefficient? The case of the "Halloween Indicator." Finance Research Letters, 11(2), 112-121. https://doi.org/10.1016/j.frl.2013.10.001

Eichengreen, B., Rose, A., \& Wyplosz, C. (1996). Contagious Currency Crises: First Tests. The Scandinavian Journal of Economics, 98(4), 463. https://doi.org/10.2307/3440879

Fama, E. F. (1970). Efficient Capital Markets: A Review of Theory and Empirical Work. The Journal of Finance, 25(2), 383. https://doi.org/10.2307/2325486

Fitriyani, I., \& Sari, aaMaria. (2013). Analisis January Effect Pada Kelompok Saham Indeks Lq-45 Di Bursa Efek Indonesia Tahun 2009-2011. E-Jurnal Akuntansi, 4(2), 421-438.

Frensidy, B. (2008). Analisis Pengaruh Aksi Beli-Jual Asing, Kurs, Dan Indeks Hang Seng Terhadap Indeks Harga Saham Gabungan di Bursa Efek Indonesia dengan Model GARCH. Media Riset Bisnis \& Manajemen, 8(1), 25-42.

Gumanti, T. A., \& Utami, E. S. (2002). Bentuk Pasar Efisiensi Dan Pengujiannya. Jurnal Akuntansi Dan Keuangan, 4(1), 54-68. https://doi.org/10.9744/jak.4.1.pp.54-68

Haggard, K. S., \& Witte, H. D. (2010). The Halloween effect: Trick or treat? International Review of Financial Analysis, 19(5), 379-387. https://doi.org/10.1016/j.irfa.2010.10.001

Harjito, D. A. (2010). Perubahan Musiman (Seasonality) Pasar Modal dan Efek Kontagion di Negaranegara ASEAN. Jurnal Siasat Bisnis, 14(1), 1-20. https://doi.org/10.20885/jsb.vol14.iss1.art1

Hartono, J. (2016). Teori Portofolio dan Analisis Investasi (10th ed.). Yoyakarta : BPFE.

Hayati, R., Irman, M., \& Agia, L. N. (2020). Sell in May and Go Away or Just Another January Effect? Studied of Anomaly in Indonesia Stock Exchange. International Journal of Economics Development Research (IJEDR), 1(1), 45-56. https://doi.org/10.37385/ijedr.v1i1.27

Hayes, A. (2019). October Effect. Investopedia. (https://www.investopedia.com/terms/o/octobereffect.asp, diakses pada 15 Januari 2020)

Hirsch, J. A. (2015). Stock Trader's Almanac. New Jersey : John Wiley \& Sons, Inc.

Husnan, S. (2002). Manajemen Keuangan Teori Dan Praktek. Yogyakarta : Yayasan Badan Penerbit Gajah Mada

Jones, C. P. (1997). Investments: Analysis and Management. New Jersey : John Wiley \& Sons, Inc.

KSEI. (2018). Berita Pers 21 Tahun KSEI: Inovasi Untuk Kenyamanan Transaksi di Pasar Modal. In Www.Ksei.Co.Id.

(www.ksei.co.id/.../156_berita_pers_21_tahun_ksei_inovasi_untuk_kenyamanan_transaksi_di_p asar_modal, diakses pada 8 September 2019)

Laeven, L., \& Valencia, F. (2013). Systemic banking crises database. IMF Economic Review, 61(2), 225-270. https://doi.org/10.1057/imfer.2013.12

Lean, H. H. (2011). The Halloween puzzle in selected Asian stock markets. International Journal of Economics and Management, 5(2), 216-225.

May, E. (2017). Smart Trader Rich Investor. Jakarta : Gramedia Pustaka Umum.

Oro, O. N. (2013). Foreign Portofolio Flows and Stock Market Performance in. School of Economics, 
March, 1-34.

Scoot, G. (2019). Halloween Strategy. Investopedia. (https://www.investopedia.com/terms/h/halloween-strategy.asp, diakses pada 11 Desember 2019)

Sugiyono, S. (2017). Statistika Untuk Penelitian (28th ed.). Bandung : Alfabeta.

Tandelilin, E. (2017). Pasar Modal: Manajemen Portofolio dan Investasi (G. Sudibyo (ed.); Edisi Digital). Yogyakarta : Kanisus.

Triatmojo, Y. (2019). Asia Tenggara Menjadi Tempat Investasi Tervaforit di Tahun 2019. Bussiness Insight Kontan. (http://amp.kontan.co.id/news/asia-tenggara-menjadi-tempat-investasitervaforit-di-tahun-2019, diakses pada 15 Okober 2019)

Wicaksana, Satria Bagus; Asandimitra, N. (2018). Halloween Efek di Bursa Efek Indonesia. Management Academic Research Society (HRMARS), 8(2018).

Yang, T., \& Lim, J. J. (2004). Crisis, contagion, and East Asian stock markets. In Review of Pacific Basin Financial Markets and Policies (Vol. 7, Issue 1, pp. 119-151). https://doi.org/10.1142/S0219091504000068

Zhang, C. Y., \& Jacobsen, B. (2013). Are monthly seasonals real? A three century perspective. Review of Finance, 17(5), 1743-1785. https://doi.org/10.1093/rof/rfs035 